\title{
Pengaruh Celebrity Endorsement Terhadap Keputusan Menginap Di Cottage Daarul Jannah
}

\author{
Superwiratni \\ Akademi Pariwisata NHI Bandung \\ Niek.kbih.dt@gmail.com
}

\begin{abstract}
This research can be reference in the promotion of the use of celebrity endorser of guests staying at the Cottage Daarul Jannah. Formulation of the problem in the study of how the influence of celebrity endorser views of four dimensions: visibility, credibility, attraction, power of guests staying at the Cottage Daarul Jannah. By using the t test or testing in partial dimensions, visibility and credibility in the variable Celebrity endorsement do not affect significantly, whereas the dimension of the attraction and power has influence significantly. Testing by using the $F$ test simultaneously or together the whole dimension of the celebrity endorsement effect significantly against the decision of the guest's stay.
\end{abstract}

Keywords - celebrity endorser; visibility; credibility; attraction; power; decision to stay

Abstrak-Penelitian ini dapat dijadikan acuan dalam promosi menggunakan celebrity endorser terhadap keputusan tamu menginap di Cottage Daarul Jannah. Rumusan masalah dalam penelitian ini bagaimana pengaruh celebrity endorser dilihat dari empat dimensi: visibility, credibility, attraction, power terhadap keputusan tamu menginap di Cottage Daarul Jannah. Dengan menggunakan uji t atau pengujian secara parsial dimensi visibility dan credibility dalam variabel celebrity endorsement tidak berpengaruh secara signifikan, sedangkan dimensi attraction dan power memilki pengaruh secara signifikan. Pengujian dengan menggunakan uji F secara simultan atau bersama-sama seluruh dimensi celebrity endorsement berpengaruh secara signifikan terhadap keputusan tamu menginap.

Kata kunci-Celebrity endorser; visibility; credibility, attraction, power; keputusan menginap.

\section{PENDAHULUAN}

Pariwisata selalu berkaitan erat dengan akomodasi. Hal ini membuat banyak bertumbuhnya hotel-hotel di Indonesia dan di Bandung pada khususnya mulai dari hotel berbintang, hotel budget, hotel MICE, wisma, vila, losmen, guest house, home stay yang menawarkan harga yang cukup bersaing.

Pada saat ini fenomena yang sedang berkembang adalah mempromosikan suatu produk atau jasa dengan menggunakan orangorang terkenal atau celebrity endorsement agar pangsa pasar yang dituju menjadi tepat sasaran. Penggunaan celebrity endorsement memiliki untung dan rugi dimana ketika personality celebrity tersebut bermasalah maka image yang ditimbulkan juga akan ikut menjadi buruk dan berimbas pada produk atau jasa yang diiklankan, namun apabila celebrity tersebut sedang naik daun maka berimbas baik pula terhadap produk dan jasa yang diiklankan.

Seperti halnya celebrity endorsement fenomena hotel syariah juga sedang booming di Indonesia dimana target pasar terbesar adalah wisatawan dari Arabsaudi, Timur tengah, Asia Tenggara seperti Malaysia dan Negara tetangga lainya, hal ini lah yang menimbulkan banyak bemunculan hotel-hotel bernuansa syariah. Aa Gym dan Ustad Yusuf Mansur adalah dua orang pendakwah yang juga memiliki Hotel syariah dimana keduanya selain menjadi pemilik juga sebagai celebrity endorsement bagi jasa akomodasinya.

Dalam penelitian ini penulis hanya membahas tentang celebrity endorsement terhadap keputusan tamu menginap di Cottage Daarul Jannah sebagai tempat penelitian. Salah satu strategi promosi yang menguntungkan dari Cottage Daarul Jannah karena menggunakan celebrity endoser KH.Abdullah Gymnastiyar (Aa Gym) seorang Da'I kondang yang notabene sebagai pemilik dari Cottage Daruul Jannah.

Untuk kembali meningkatkan occupancy di Cottage Daarul Jannah, dibuatlah beberapa strategi dan merubah target pasar namun sampai saat ini belum membantu menaikan occupancy secara signifikan khususnya kepada wisatawan personal dan grup untuk menginap di Cottage Daarul Jannah. Dengan kondisi diatas menarik penulis untuk melakukan penelitian dan menganalisa dengan mengambil judul "Pengaruh Celebrity endorsement Terhadap Keputusan Menginap di Cottage Daarul Jannah". Berdasarkan latar belakang 
penelitian diatas, pertanyaan penelitian ini yaitu:

1. Bagaimana Pengaruh Celebrity endorsement?

2. Bagaimana Keputusan Tamu menginap di Cottage Daarul Jannah?

\section{KAJIAN PUSTAKA}

\section{A. Periklanan}

Salah satu alat komunikasi yang sudah lazim dan paling utama adalah periklanan. Terance A Shimp (2014:15) menuturkan bahwa Periklanan merupakan alat komunikasi pemasaran yang utama. Periklanan merupakan usaha komunikasi pemasaran yang dilakukan oleh organisasi atau perusahaan untuk memberikan informasi melalui media. Dalam periklanan sebuah produk dapat menampilkan dan memberikan informasi melalui pesan yang mampu mengajak, menggugah rasa dan mempertahankan daya ingat costumer terhadap produk yang ditawarkan yang pada akhirnya dapat mempengaruhi konsumen untuk melakukan pembelian. Fungsi periklanan menurut Terance A Shimp (2014:198) yaitu:

\section{Memberikan informasi}

Iklan memberikan informasi yang bernilai baik untuk merek yang dipromosikan dan konsumen dengan mengerjakan penggunaan baru untuk merek yang sudah ada.

\section{Memberikan Pengaruh}

Target costumer untuk mencoba, membeli dan menggunakan jasa yang telah ditawarkan akan dipengaruhi oleh Iklan yang tepat. terkandung iklan mempengaruhi permintaan dasar yaitu menciptakan permintaan untuk seluruh kategori produk.

3. Mengingatkan dan meningkatkan kesadaran merek

Iklan membuat merek perusahaan selalu ada dalam pikiran konsumen, kemungkinan konsumen akan menjadikan produk itu sebagai kandidat produk yang akan di beli, ini yang membuat merek menjadi menonjol.

\section{Menambah nilai}

Menambah nilai penawaran yaitu inovasi, meningkatkan kualitas, dan mengubah persepsi konsumen. Nilai brand, akan bertambah nilainya dengan iklan karena mampu memengaruhi pandangan konsumen. Iklan yang tepat menyebabkan brand akan dipandang lebih elegan, lebih bergaya, lebih prestisius, lebih berkualitas dan sebagainya.

5. Membantu upaya lain perusahaan.
Iklan menjual lebih dulu produk sebuah perusahaan dan penyediaan periklanan dan pendahuluan bagian penjualan saat berhadapan secara langsung dan pribadi dengan konsumen yang potensial.

\section{B. Celebrity Endorsement}

Mowen dan Minor (2002:401) Membagi sumber pesan menjadi empat bagian, yaitu; celebrity endorsement, experts endorser, typical persons endorser, karakter tertentu yang diciptakan, biasanya seperti animasi ciptaan manusia.

Di dalam mengiklankan produk sering kali menggunakan dukungan kaum selebriti dan juga non selebriti. Definisi selebriti diungkapkan Terence A. Shimp (2003:460) sebagai tokoh entah itu sebagai actor, atlet, ataupun entertainment dan lainnya yang dikenal masyarakat karena prestasinya didalam bidang-bidang tertentu yang berbeda dari golongan produk yang didukung

Celebrity endorsement menurut Terence A. Shimp (2014:335) adalah bintang televisi, atau film, atlet yang terkenal dan ada kalanya selebriti yang telah meninggal yang secara luas digunakan pada iklan majalah, radio sport, iklan televisi yang mendukung suatu produk.

Celebrity endorsement atau personal yaitu sebagai actor \& aktris, penghibur atau atlit yang dikenal oleh masyarakat karena kecakapannya dalam bidang tertentu yang mampu menyokong produk kita untuk dipromosikan. Personal yang memiliki ciri-ciri tadi dapat dijadikan strategi sebagai alat yang pas demi mewakili segmen pasar yang dibidik. Untuk mengukur celebrity endorsement menggunakan variabel visibility, credibility, attraction, dan power. Rossiter dan Percy dalam Royan(2005:12).

Celebrity endorsement ditujukan untuk menarik perhatian konsumen dengan tujuan mempengaruhi konsumen untuk melakukan pembelian/ menginap di hotel atau membeli produk atau jasa. Proses penjualan mengidentifikasi perlengkapan kegiatan penjualan untuk menggerakan pembeli dari kesadaran kebutuhan terhadap keputusan menginap.

Celebrity endorsement merupakan alat promosi yang popular di dunia dikarenakan menggunakan selebriti dapat menarik, menyenangkan dan dapat dipercaya oleh publik sehingga produk yang di promosikan dapat diketahui dan dikenal oleh konsumen. Celebrity endorsement merupakan bagian yang terpenting dari sebuah strategi promosi kampanye pemasaran suatu produk. Harapan 
dari pengguna celebrity endorsement adalah image atau kualitas seberitis akan berpindah kepada produk dan merangsang penjualan, Leslie,( $2011: 272)$.

Rossiter dan Percy dalam Royan (2005:34) menyatakan salah satu alternative untuk mengevaluasi selebriti dalam periklanan dengan memakai metode VisCAP, yaitu:

\section{Visibility}

Visibility mempunyai dimensi seberapa besar popularitas selebriti tersebut. Apabila digabungkan dengan ketenaran, maka akan bermanfaat jika tujuan komunikasinya adalah brand awareness.

\section{Credibility}

Dua hal utama yang selalu dikaitkan dengan kredibilitas, yang pertama ialah kecakapan dan objektifitas. Keahlian berisi mengenai tingkat pengetahuan tokoh tersebut tentang produk yang dipasarkan, dan objektivitas lebih mengarah pada ability tokoh tersebut untuk meyakinkan, membujuk dan menimbulkan rasa percaya diri pada konsumen suatu produk. Selebriti akan sesuai apabila communication objective adalah brand attitude, dimana brand attitude memiliki artian kemampuan brand tersebut dalam mewujudkan dorongan dan hasrat serta emosi yang sesuai dengan keuntungan brand.

\section{Attraction}

Menitik beratkan pada daya tarik sang bintang yang menyangkut dua hal yaitu tingkat disukai (likeability) dan tingkat kesamaan dengan kepribadian selebriti yang menjadi keinginan target pengguna merek, minimal selebriti wajib mencerminkan personal dan brand yang diciptakan melalui iklan. Image seseorang selebriti harus sama dengan image produk yang akan didukungnya.

\section{Power}

Power merupakan suatu kemampuan selebriti dalam menarik konsumen untuk membeli produk yang ditawarkan. Unsur terakhir ini memiliki artian tokoh terkenal yang dijadikan model dalam iklan ini wajib mempunyai daya yang besar untuk memerintahkan target konsumen

Keputusan menginap mengadopsi dari pengertian keputusan pembelian dari Kotler \& Armstrong (2012:154) Yang dimana memiliki karakteristik yang sama diantara keputusan pembelian dengan keputusan menginap yang menyatakan kegiatan keputusan dalam pembelian yang dilakukan konsumen adalah membeli merk (brand) yang paling disukainya.
Keputusan menginap diambil dari pengertian minat berkunjung, keputusan menginap muncul sebab adannya pengukuran objektif ataupun karena faktor emosi, keputusan untuk bertindak merupakan serangkaian dari aktifitas yang bisa digambarkan pada proses menginap. Memahami prilaku wisatawan/ tamu hotel atau cottage tidaklah mudah karena wisatawan/tamu hotel atau cottage memutuskan untuk menginap dengan alasan yang berbeda serta sangat beragam dalam hal usia, income, pendidikan dan selera tentang proses keputusan menginap.

\section{Kerangka Pemikiran}

Kerangka pemikiran yang penulis ajukan untuk menunjukan adannya pengaruh celebrity endorsement dan Tingkat hunian kamar dengan menggunakan teori dari Rossiter dan Percy dalam Royan (2005:34) untuk celebrity endorsement dan menggunakan teori kotler dan Keller (2012:170) dalam Romanah, (2014:51) untuk keputusan tamu menginap, dapat digambarkan pada gambar dalam kerangka pemikiran sebagai berikut:

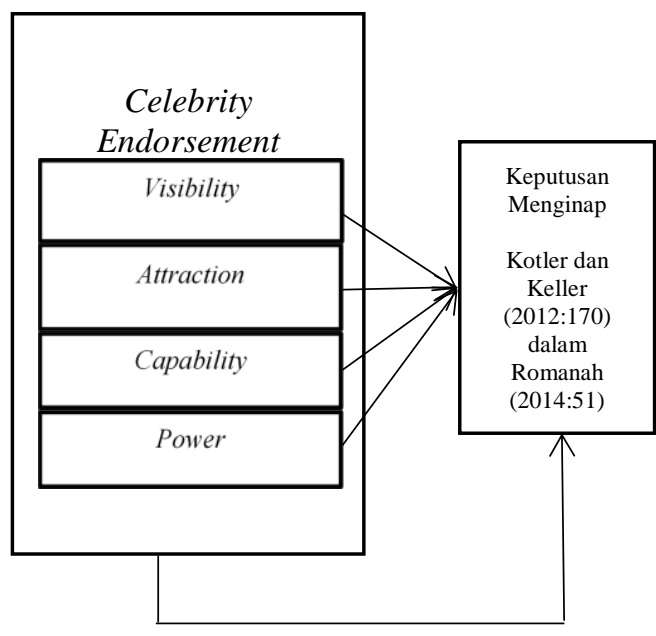

GAMBAR 1. KeRANGKA PEMIKIRAN

\section{Hipotesis}

Hipotesis merupakan jawaban sementara terhadap masalah penelitian yang kebenarannya harus di uji secara empirik. Sugiono (2009:84) mengatakan bahwa hipotesis sebagai jawaban sementara terhadap rumusan masalah berupa pernyataan tentang hubungan dua variabel atau lebih, perbandingan (komparasi), atau variabel mandiri (deskripsi). Hipotesis dapat dibedakan menjadi 2:

1. $\mathrm{H}_{\mathrm{a}}$ yang merupakan hipotesis alternative yang mana ada pengaruh antara variabel $\mathrm{X}$ dan $\mathrm{Y}$. 
2. $\mathrm{H}_{0}$ yang merupakan hipotesis nol atau bisa dikenal dengan hipotesis statistic yang mana variabel $X$ tidak ada pengaruh terhadap variabel Y.

\section{Metode Penelitian}

\section{A. Jenis Penelitian}

Jenis penelitian memberikan informasi mengenai model penelitian yang digunakan beserta prosedur penelitian.Sugiyono (2009:1) berpendapat bahwa metode penelitian adalah pada dasarnya merupakan cara ilmiah untuk mendapatkan data dengan tujuan tertentu.

Penelitian ini adalah penelitian kuantitatif karena menggunakan berbagai metode statistik untuk mengukur data. Penelitian kuantitatif dilakukan untuk menghitung angka, volume dan nilai seperti jumlah pelanggan, penumpang, warga, pengunjung, ruang hunian kamar, penjualan dan kepuasan (Bowie dan Buttle, 2004:45).

\section{B. Objek Penelitian}

Objek penelitian dilakukan di Cottage Daarul Jannah Jalan Gegerkalong Girang No.67 Bandung, bernuansa eksklusif dan alami, berada di lingkungan Pesantren Daarut Tauhiid yang merupakan milik KH. Abdulah Gymnastiyar (Aa Gym).

Penelitian ini menganalisis mengenai Pengaruh celebrity endorser terhadap keputusan tamu menginap di Cottage Daarul Jannah. variable bebas dalam penelitian ini adalah celebrity endorser (X) yang terdiri dari beberapa sub variabel yaitu visibility (X1), capability (X2), attraction (X3), power (X4) serta variable terikat dalam penelitian ini ialah keputusan tamu menginap (Y) yang terdiri dari pemilihan brand, waktu kunjungan, jumlah kunjungan, metode pembayaran. Maka populasi penelitian ini ialah semua tamu yang menginap di Cottage Daarul Jannah dalam kurun waktu satu tahun di tahun 2015-2016.

\section{Sampel}

Populasi memiliki bagian-bagaian didalamnya yang memiliki karakteristik tertenrtu, bagian bagian tersebut disebut dengan sampel, ungkap sugiyono dalam buku metode penelitiannya (2010:116). maka dalam rangka untuk mempermudah penelitian diperlukan suatu sampel, hal ini disebabkan oleh faktor dana, tenaga dan waktu. Maka penelitian dibolehkan mengambil sebagian dari objek populasi yang telah ditentukan dengan syarat bagian yang diambil tersebut merupakan wakil dari bagian yang lain yang diteliti.
Sampel yang digunakan dalam penelitian ini adalah sebagian dari populasi penelitian, yaitu sebagian dari jumlah tamu Cottage Daarul Jannah. Khususnya tamu individu yang menginap pada tahun 2015 yang berjumlah 2.375 orang. Penulis hanya memilih populasi tamu individu untuk dijadikan sampel karena jumlahnya yang jauh lebih banyak dari tamu Grup.

D. Teknik Pengujian Data Validitas dan Reliabilitas

Mengingat pengumpulan data dilakukan dengan menggunakan kuesioner, maka setelah data diperoleh dari responden melalui kuesioner terkumpul, langkah selanjutnya adalah dilakukan pengujian validitas dan reliabilitas

\section{E. Analisis Regresi Linear Berganda}

Analisis regresi linear berganda adalah suatu analisis peramalan nilai pengaruh dua atau lebih variable bebas celebrity endorsement (X) terhadap variable terkait keputusan menginap (Y) untuk membuktikan ada atau tidaknya hubungan kausal antara dua variable bebas atau lebih. Adapun untuk pengolahan data dilakukan bantuan program SPSS versi 22 for Windows.

Menejemahkan dalam beberapa sub hipotesis yang menyatakan pengaruh sub variabel independen yang paling dominasi terhadap variabel dependen, lebih jelasnya dapat dilihat pada gambar berikut ini:

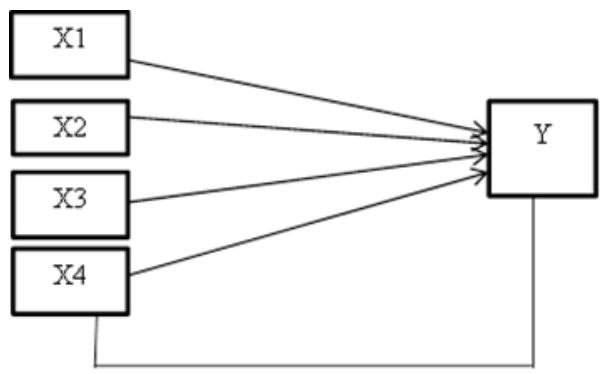

Keterangan:

$$
\begin{array}{ll}
\text { X1 } & =\text { Visibility } \\
\text { X2 } & =\text { Capability } \\
\text { X3 } & =\text { Attraction } \\
\text { X4 } & =\text { Power } \\
\text { Y } & =\text { Keputusan Menginap }
\end{array}
$$

GAMbar 2. PARAdigma Penelitian 


\section{F. Asumsi Klasik}

1. Uji Normalitas

Uji normalitas digunakan untuk melihat apakah residual terdistribusi normal atau tidak. Model regresi yang baik adalah memiliki nilai residual yang terdistribusi normal. Untuk itu penulis melakukan uji normalitas dengan menggunakan bantuan program SPSS 22

\section{Uji Multikolinearitas}

Multikolinieritas merupakan suatu gejala yang terjadi pada sampel, pada salah satu asumsi regresi linier berganda adalah bahwa tidak terjadi korelasi yang signifikan antara variabel bebasnya (Umar, Husain, 2003). Penyimpangan asumsi kelasik ini karena adanya multikolinieritas dalam model regresi yang dihasilkan. Artinya antara variabel independen yang terdapat dalam model memiliki hubungan kjyang sempurna atau mendekati sempurna. Cara untuk menguji tidak adanya multikolinieritas dapat dilihat pada Tolerance Value atau Variance Inflation Faktor.

\section{Uji Heteroskedastisitas}

Uji homoskedasitas pada prinsipnya digunakan untuk menguji apakah sebuah grup memiliki varians yang sama diantara anggota grup tersebut. Jika varians sama dan data ini seharusnya terjadi, maka dikatakan ada homoskedasitas. Sedangkan jika varians tidak sama, dikatakan terjadi heterokedasitas (Santoso,2003). Jika probabilitas dari hasil korelasi tersebut lebih besar dari pada taraf signifikansi yang diharapkan $(0,5)$ maka terjadi homokedasitas. Sebaliknya, jika probabilitas dari hasil korelasi tersebut lebih kecil atau sama dengan taraf signifikansi yang diharapkan $(0,05)$ maka terjadi heterokedasitas. Pengujian akan dilakukan dengan menggunakan alat bantu program SPSS versi 22.

\section{Uji t}

Uji $t$ digunakan untuk mengetahu hubungan antara variable independent dan variable depend dengan cara membandingkan nilai t hitung dan t tabel. Sugiyono (2010: 199)

\section{G. Pengujian Hipotesis}

Pengujian hipotesis dalam penelitian ini dengan cara membandingkan antara nilai probabilitas $t$ tes untuk pengujian parsial dan probabilitas $\mathrm{F}$ untuk simultan dengan $\alpha$ sebesar 0,05 (5\%), dengan ketentuan sebagai berikut:

1. Pengaruh Simultan a. Jika Probabilitas F tes > 0,05 maka Ho diterima.

b. Jika Probabilitas F tes $\leq$ maka 0,05 maka Ha diterima

2. Pengaruh Parsial

a. Jika Probabilitas t tes $>0,05$ maka Ho diterima

b. Jika Probabilitas $\mathrm{t}$ tes $\leq 0,05$ maka Ho ditolak atau Ha diterima

H. Jadwal dan Waktu Penelitian

Waktu penelitian dimulai pada Desember sampai Februari 2016

\section{Hasil PENElitian dan PEMBahasan}

Cottage Daarul Jannah berlokasi di Jl. Gegerkalong Girang No. 67 Bandung yang berada didalam lingkungan Pesantren Daarut Tauhiid Bandung. Konsep Cottage Daarul Janaah berupa rumah taman dengan arsitektur rumah kayu yang mencirikan rumah tradisional Sunda dengan lingkungan yang nyaman, sejuk dan segar.

Cottage Daarul Jannah memiliki 24 kamar yang terdiri dari 2 jenis tipe kamar yaitu: 12 kamar standar (Twin bed), 4 kamar standar (Double bed), 8 kamar Deluxe (double bed). Adapun fasilitas yang dimiliki: Meeting Room, Supermarket Daarut Tauhiid, ATM Center, Laundry, Masjid Daarut Tauhiid, Car \& Elf Rental, MICE \& Tour.

Room rate yang dimiliki oleh Cottage Daarul Jannah dapat dilihat pada tabel berikut ini:

TABEL 1. JENIS KAMAR DAN HARGA YANG DIMILIKI COTTAGE DAARUL JANNAH

\begin{tabular}{ccc}
\hline No. & Tipe Kamar Hotel & Harga \\
\hline 1. & Standard room (twin bed) & Rp. 467.500 \\
\hline 2. & $\begin{array}{c}\text { Standard room (double } \\
\text { bed) }\end{array}$ & Rp. 467.500 \\
\hline 3. & Duluxe (Double bed) & Rp. 550.000 \\
\hline Sumber: Manajemen Cottage Daarul Jannah &
\end{tabular}

A. Pengaruh Celebrity endorsement Terhadap Keputusan Menginap di Cottage Daarul Jannah

Penelitian ini dilakukan untuk mengetahui bagaimana pengaruh celebrity endorsement terhadap keputusan tamu menginap di Cottage Daarul Jannah dengan menggunakan analisis regresi linier berganda yang terdiri dari persamaan regresi linier berganda, analisis koefisien determinasi dan pengujian hipotesis.

\section{Uji Validitas}

Uji validitas digunakan untuk mengetahui tingkat kecermatan suatu alat ukur dalam menjalankan fungsi ukurnya. Kriteria yang digunakan valid atau tidak, valid jika koefisien 
korelasi t yang diperoleh lebih dari atau sama dengan koefisien di tabel nilai-nilai kritis t, yaitu pada taraf signifikansi $5 \%$ instrument tes yang diujicobakan tersebut dinyatakan valid. Uji validitas dilakukan dengan menggunakan perhitungan product moment terhadap itemitem kuesioner dengan program computer statistik. Dasar pertimbangan untuk mengukur valid tidaknya kuesioner adalah dengan membandingkan antara thitung (ryx) terhadap $t$ tabel. Nilai $\mathrm{t}$ tabel untuk penelitian ini adalah $\mathrm{t}$ tabel dengan df $=(n-2)=27$ pada $\alpha=5 \%$ yaitu 0,865 . Jika t hitung lebih besar dari t tabel maka kuesioner dikatakan valid dan sebaliknya jika $\mathrm{t}$ hitung lebih kecil dari t tabel maka kuesioner tersebut dikatakan valid sebagai instrument penelitian

\section{Uji Reliabilitas}

Uji reabilitas dilakukan untuk mengetahui sejauh mana hasil pengukuran tetap konsisten apabila dilakaukan pengukuran dua kali atau lebih terhadap objek yang sama dengan alat ukur yang sama. Selanjutnya untuk mengetahui reliabilitas dari pertanyaan-pertanyaan dalam kuesioner, digunakan teknik Cronbach's Alpha. Suatu instrument dianggap reliable, apabila koefisien alpha diatas 0,6. Perhitungan uji reliabilitas dilakukan dengan program statistik.

\section{B. Asumsi Klasik}

\section{Uji normalitas}

Untuk menguji distribusi apakah berdistribusi normal atau tidak, maka dilakukan uji normalitas, uji normalitas adalah uji klasik terakhir yang digunakan sebelum melakukan uji regresi linier berganda, dengan menggunakan diagram normal probability plot seperti yang terlihat dibawah ini:

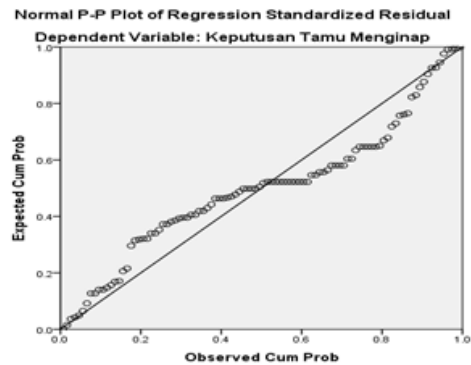

Sumber: Hasil olahan SPSS, 2016

GAMBAR 3 GRAFIK UII NORMALITAS

Gambar 3 mempertegas bahwa model regresi yang di peroleh berdistribusi normal dimana sebaran data mengikuti garis diagonal, sehingga tidak terjadi pelanggaran pada uji normalitas.

\section{Uji Multikolinearitas}

Multikolinealitas merupakan gejala yang terjadi pada sampel, pada salah satu asumsi regresi kinuer berganda adalah bahwa tidak terjadi korelasi yang signifikan antara variabel bebasnya (Umar, 2003). Penyimpangan asumsi kelasik ini karena adanya Multikolinealitas dalam model regresi yang dihasilkan. Artinya antara variabel independen yang terdapat dalam model memiliki hubungan yang sempurna atau mendekati sempurna. Cara untuk menguji tidak adanya Multikolinealitas dapat dilihat pada Tolerance value atau Variance Information Factor (VIF). Tabel dibawah ini:

TABEL 2. HASIL UJI MULTIKOLINEARITAS

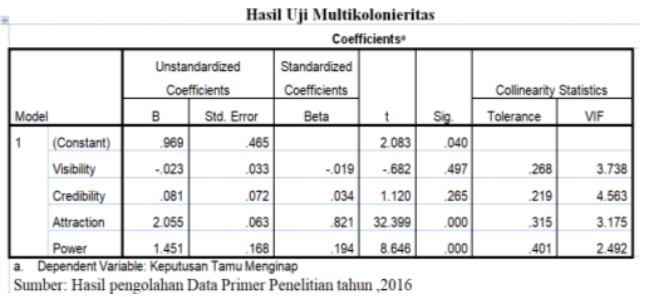

Tabel 1 menunjukan bahwa nilai VIF variabel kurang dari nilai 10. Dengan demikian pada model regresi yang digunakan tidak terjadi multikolonieritas.

\section{Uji Heteroskedatisidas}

Jika asumsi yang kedua dari model regresi yang baik adalah tidak memenuhi heteroskedastisitas. Jika nilai $\mathrm{t}$ hitung lebih kecil dari t tabel pada taraf $5 \%$ maka tidak terjadi heteroskedastisitas, begitu pun sebaliknya. Berikut ini adalah gambar hasil pengujian heteroskedastisitas.

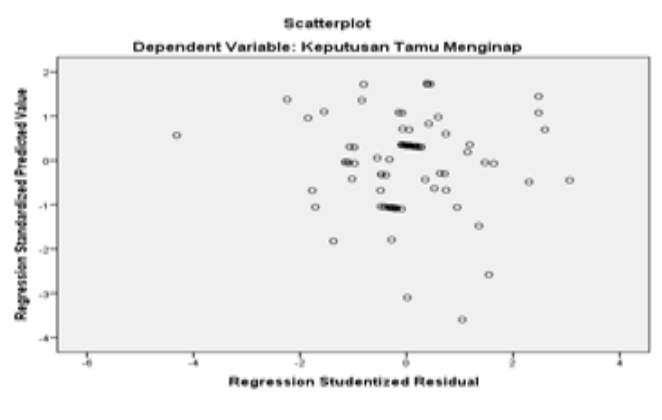

Sumber: Hasil olah data SPSS (2016)

GAMBAR 4 GRAFIK UJI HETEROSKEDASTISITAS

Terlihat grafik scatterplot diatas bahwa titik tidak menyebar secara acak baik dibawah angka 0 pada sumbu Y. Hal ini menyimpulkan bahwa terjadi Heterokedastisidas model regresi. Maka data yang kita gunakan memenuhi syarat untuk dilakukan regresi berganda. 


\section{Regresi Linier Berganda}

Uji regresi linier berganda dilakukan untuk memprediksi apakah variabel $\mathrm{X}$ berpengaruh terhadap variabel $\mathrm{Y}$ dan seberapa besar pengaruh keempat variabel bebas terhadap variabel terikat $\mathrm{Y}$, Uji regresi linier berganda terdiri dari Uji secara simultan (Uji F) dan Uji secara parsial (Uji T).

\section{Uji t}

Uji t digunakan untuk mengetahui apakah variabel-variabel independen (visibility, credibility, attraction, power) secara parsial berpengaruh nyata atau tidak terhadap variabel dependen (keputusan tamu menginap). Derajat signifikansi yang digunakan adalah 0,05. Apabila nilai signifikansi lebih kecil dari derajat maka diterima hipotesis alternative, yang menyatakan bahwa suatu variabel independen secara parsial mempengaruhi variabel dependen. Langkah pengujian sebagai berikut:

\section{TABEL 3. HASIL UJI T}

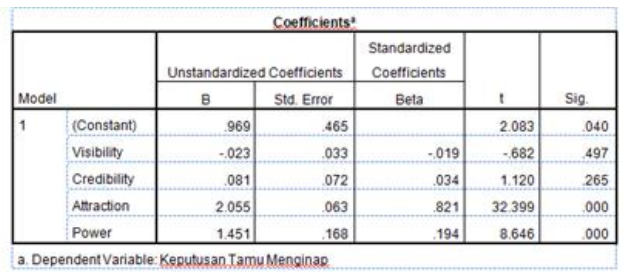

Sumber: Hasil olah data (2016)

Dari tabel diatas diperoleh persamaan sebagai berikut:

\section{$\mathrm{Y}=$ 0,969-0,023X1+0,081X2+2.055X3+1,451X4}

Dari hasil persamaan regresi linier berganda tersebut masing-masing variabel dapat diinterprestasikan sebagai berikut:

a. Konstanta sebesar 0,969 menyatakan bahwa ketika semua variabel bebas bernilai 0 (nol) dan tidak ada perubahan, maka celebrity endorserment akan bernilai 0,969.

b. Nilai variabel $\mathrm{X} 1$ yaitu visibility memiliki nilai koefisien regresi sebesar $-0,023$, artinya ketika visibility mengalami peningkatan, sementara variabel bebas lainnya $(\mathrm{X} 2, \mathrm{X} 3, \mathrm{X} 4)$ konstan, maka celebrity endorsement akan menurun 0,023 .

c. Nilai variabel X2 yaitu Credibility memiliki nilai koefisien regresi sebesar 0,081 artinya jika credibility mengalami peningkatan, sementara variabel bebas lainnya (X1,X3,X4) konstan, maka celebrity endorsement akan meningkat sebesar 0,081. d. Nilai variabel X3 yaitu attraction memiliki nilai koefisien regresi sebesar 2.055 artinya jika attraction mengalami peningkatan sementara variabel bebas lainnya $(\mathrm{X} 1, \mathrm{X} 2, \mathrm{X} 4)$ konstan, maka celebrity endorsement akan meningkat sebesar 2.055.

e. Nilai variabel X4 yaitu power memiliki nilai koefisien regresi sebesar 1,451 artinya jika power mengalami peningkatan sementara variabel bebas lainnya $(\mathrm{X} 1, \mathrm{X} 2, \mathrm{X} 3)$ konstan, maka celebrity endorsement akan meningkat sebesar 1,451.

Hipotesis dalam penelitian ini adalah:

Ho: $b_{i}=0$; artinya secara parsial tidak ada pengaruh yang signifikan dari variabel-variabel independen (visibility,credibility, attraction, power) terhadap variabel terikat (keputusan menginap).

H1: $b_{i} \neq 0$; artinya secara parsial ada pengaruh yang signifikan dari variabel-variabel independen (visibility,credibility, attraction, power) terhadap variabel terikat (keputusan tamu menginap).

Dengan menggunakan taraf signifikansi $(\alpha)$ $=$ dan $\mathrm{df}($ degree of freedom $)=\mathrm{n}-\mathrm{k}-1 \quad(\mathrm{df}=97)$ diperoleh nilai $\mathrm{t}$ sebesar 1,661. Jika t hitung $>\mathrm{t}$ tabel atau $-\mathrm{t}$ hitung < - $\mathrm{t}$ tabel maka Ho ditolak dan H1 diterima, artinya secara individual ada pengaruh yang signifikan variabel bebas terhadap variabel tidak bebas. Jika $t$ hitung $<\mathrm{t}$ tabel atau - $t$ hitung $>-t$ tabel maka Ho diterima dan $\mathrm{H} 1$ ditolak, artinya secara individual tidak ada pengaruh yang signifikan variabel bebas terhadap variabel tidak bebas.

\section{a. Pengujian variabel Visibility}

Keriteria hipotesis yang diajukan:

Ho : $\mathrm{b} 1=0$ berarti tidak ada pengaruh secara parsial dimensi visibility terhadap keputusan menginap.

H1 $:$ b1 $\neq 0$ berarti ada pengaruh secara parsial dimensi visibility terhadap variabel keputusan menginap.

Berdasarkan hasil perhitungan diperoleh nilai t hitung $(-682)<\mathrm{t}$ tabel $(1,661)$ sehingga hipotesis nol (Ho) diterima dan hipotesis (H1) ditolak. Dengan ditolaknya $\mathrm{H} 1$ berarti dimensi visibility pada variabel celebrity endorsement tidak berpengaruh secara signifikan terhadap keputusan menginap.

\section{b. Pengujian variabel Credibility}

Ho : b2 = 0 berarti tidak ada pengaruh secara parsial variabel credibility terhadap keputusan menginap. 
$\mathrm{H} 1: \mathrm{b} 2 \neq 0$ berarti ada pengaruh secara parsial variabel credibility terhadap variabel keputusan menginap.

Berdasarkan hasil perhitungan diperoleh nilai t hitung $(1,120)<\mathrm{t}$ tabel $(1,661)$ sehingga hipotesis nol (Ho) diterima dan hipotesis (H1) ditolak. Dengan ditolaknya H1 berarti dimensi credibility pada variabel celebrity endorsement tidak berpengaruh secara signifikan terhadap keputusan menginap.

\section{c. Pengujian variabel Attraction}

Ho : $\mathrm{b} 3=0$ berarti tidak ada pengaruh secara parsial variabel attraction terhadap keputusan menginap.

$\mathrm{H} 1: \mathrm{b} 3 \neq 0$ berarti ada pengaruh secara parsial variabel attraction terhadap variabel keputusan menginap.

Berdasarkan hasil perhitungan diperoleh nilai $\mathrm{t}$ hitung (32.399) $>\mathrm{t}$ tabel $(1,661)$ sehingga hipotesis nol (Ho) ditolak dan hipotesis (H1) diterima. Dengan diterimanya H1 berarti dimensi credibility pada variabel celebrity endorsement berpengaruh secara signifikan terhadap keputusan menginap.

\section{d. Pengujian variabel Power}

Ho : b4 = 0 berarti tidak ada pengaruh secara parsial variabel power terhadap keputusan menginap.

H1 : b4 $\neq 0$ berarti ada pengaruh secara parsial variabel power terhadap variabel keputusan menginap.

Berdasarkan hasil perhitungan diperoleh nilai $\mathrm{t}$ hitung $(8,646)>\mathrm{t}$ tabel $(1,661)$ sehingga hipotesis nol (Ho) ditolak dan hipotesis (H1) diterima. Dengan ditolaknya Ho berarti dimensi power pada variabel celebrity endorsement tidak berpengaruh secara signifikan terhadap keputusan menginap.

\section{Uji F}

Uji $\mathrm{F}$ digunakan untuk mengetahui apakah variabel-variabel independen secara simultan berpengaruh signifikan terhadap variabelvariabel dependen. Derajat kepercayaan digunakan adalah 0,05 . Apabila nilai $F$ hasil perhitungan lebih besar dari pada nilai $F$ menurut tabel maka hipotesis alternative yang menyatakan bahwa semua variabel independen secara simultan berpengaruh secara signifikan terhadap variabel dependen. Seperti pada pengujian pada tabel berikut ini:
TABEL 4. HASIL UJI F

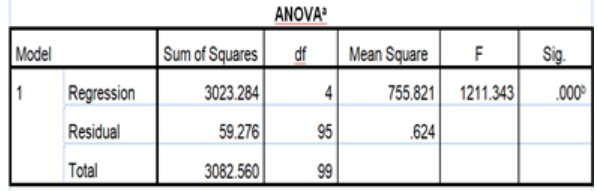

a. Dependent Variable: Keputusan Tamu Menginap

b. Predictors: (Constant), Power, Visibility, Attraction, Credibility

Uji $\mathrm{F}$ di atas menunjukan bahwa nilai $\mathrm{F}$ hitung 1211.343 dengan tingkat (sig) 000 atau dapat nilai signifikan 000 lebih kecil dari nilai probabilitas 0.05 . Hal tersebut membuktikan bahwa terdapat pengaruh yang antara variabel celebrity endorsement yang terdiri dari dimensi visibility, credibility, attraction, dan power terhadap variabel keputusan tamu menginap atau secara simultan (bersama-sama) visibility, credibility, attraction, dan power signifikan terhadap keputusan tamu menginap.

a. Menentukan Hipotesis

Ho : $\mathrm{b} 1=\mathrm{b} 2=0$, artinya secara serempak tidak ada pengaruh yang signifikan dari variabel-variabel independen celebrity endorsement (visibility,credibility, attraction, power) terhadap variabel terikat (keputusan tamu menginap).

Ha : $b 1 \neq b 2 \neq 0$, artinya secara serempak ada pengaruh yang signifikan dari variabel-variabel independen celebrity endorsement (visibility, credibility, attraction, power) terhadap variabel terikat (keputusan tamu menginap).

b. Dengan menggunakan taraf signifikansi $(\alpha)$ $=0,05$; derajat kebebasan $(\mathrm{dk})=(\mathrm{n}-\mathrm{k}-1)=$ 27 diperoleh nilai $\mathrm{F}$ Tabel $=3,09$

c. Kriteria pengujian

Ho diterima apabila $\mathrm{F}$ hitung $\leq 3,09$

Ha ditolak apabila F hitung $>3,09$

d. Hasil pengujian diperoleh $F$ hitung 1211.343 dengan dengan sing $\mathrm{F}=0,305$

Berdasarkan hasil pengujian maka dapat diketahui bahwa nilai $\mathrm{F}$ hitung keputusan tamu menginap lebih besar dari F tabel $(3,09)$ hingga Ho ditolak dan Ha diterima yang berarti secara serempak ada pengaruh yang signifikan dari variabel dari variabel bebas (celebrity endorsement) terhadap variabel terikat (keputusan tamu menginap).

\section{Penilaian Responden Terhadap Celebrity Endorsement (Aa Gym)}

Berdasarkan hasil penelitian diketahui bahwa secara umum celebrity endorsement (Aa Gym) di Cottage Daarul Jannah, berada dalam kategori baik. Dengan menggunakan uji t atau pengujian secara parsial dimensi visibility dan 
credibility dalam variabel Celebrity endorsement tidak berpengaruh secara signifikan, sedangkan dimensi attraction dan power memilki pengaruh secara signifikan. Pengujian dengan menggunakan uji $\mathrm{F}$ secara simultan atau bersama-sama seluruh dimensi celebrity endorsement berpengaruh secara signifikan terhadap keputusan tamu menginap. Hasil jawaban responden dari tiap-tiap pernyataan mengenai dimensi tersebut menggambarkan tentang celebrity endorsement (Aa Gym) yang mempromosikan tentang Cottage Daarul Jannah. Adapun penilaian responden mengenai setiap dimensi yaitu:

\section{Dimensi Visibility}

Diperoleh informasi bahwa tingkat visibility dari Celebrity endorsement (Aa Gym) muncul di media dan mempromosikan Cottage Daarul Jannah dinilai baik. Namun dengan menggunakan pengujian secara parsial atau uji $\mathrm{t}$ dimensi visibility tidak memiliki pengaruh secara signifikan terhadap keputusan tamu menginap di Cottage Daarul Jannah. Hal ini ditunjukan dari lima pertanyaan yang diajukan mengenai visibility. Adapun pertanyaanpertanyaanya antara lain: frekuensi celebrity endorsement (Aa Gym) muncul di media eletronik seperti tv, internet dan radio, pertanyaan frekuensi Aa Gym mempromosikan Cottage Daarul jannah, pertanyaan popularitas Aa Gym dikalangan masyarakat yang mengikuti pengajian di Daarut Tauhiid, pertanyaan popularitas Aa Gym dikalangan masyarakat luas dan pengenalan masyarakat kepada Aa Gym.

Setelah keputusan Aa gym berpoligami pada tahun 2006 yang mengakibatkan banyaknya jamaah khususnya ibu-ibu yang tidak suka, Aa Gym memutuskan untuk membatasi kemunculan beliau berdakwah melalui media televisi nasional namun tetap menggunakan social media dan menggunakan MQ TV yang merupakan salah satu unit bisnis Manajemen Qolbu milik Aa Gym sebagai jalan dakwah dan media promosi sehingga sebagian besar masyarakat menganggap bahwa Aa Gym telah menghilang dari layarkaca dan menurun popularitas nya sebagai seorang pendakwah yang terkenal dan mengakibatkan berkurangnya masyarakat yang mengenal Aa Gym, namun Aa Gym sebagai seorang celebrity endorsement dinilai baik .

\section{Dimensi Credibility}

Diketahui secara umum penilaian responden terhadap dimensi credibility pada variabel celebrity endorsement adalah baik dimana dari ketiga pertanyaan yang diajukan kepada responden memiliki nilai yang baik, ketiga pertanyaan tersebut antara lain: kepercayaan masyarakat terhadap Aa Gym sebagai pendakwah dan celebrity endorsement, keyakinan masyarakat kepada Aa Gym sebagai celebrity endorsement dan citra Aa Gym di masyarakat. Namun pada pengujian parsial atau uji $\mathrm{t}$ dimensi credibility tidak berpengaruh secara signifikan terhadap keputusan tamu menginap dikarenakan masyarakat pada saat ini sudah sangat objektif dan pintar untuk memilah-milah akan penilain terhadap seseorang termasuk kehidupan pribadi celebrity itu sendiri, pada saat citra Aa Gym sebagai seorang pendakwah jatuh memiliki imbas yang sangat besar terhadap unit-unit bisnis Manajemen Qolbu termasuk Cottage Daarul Jannah namun pada saat ini dengan seiring waktu unit-unit bisnis Aa Gym mulai bangkit kembali dengan menggunakan berbagai macam strategi dan citra Aa Gym sebagai pendakwah mulai terdengar lagi gaumnya sehingga penilaian responden terhadap dimensi credibility adalah baik.

\section{Dimensi Attraction}

Dapat dilihat bahwa secara umum penelian responden terhadap dimensi attraction pada celebrity endorsement memiliki penilaian yang baik dengan ketiga pertanyaan yang mendapatkan respon yang baik. Adapun ketiga pertanyaan tersebut adalah: Penampilan Aa Gym sebagai celebrity endorsement, pesona Aa Gym sebagai celebrity endorsement, kesesuaian Aa Gym sebagai seorang celebrity endorsement. Dengan pengujian secara parsial atau uji $\mathrm{t}$ dimensi attraction pada celebrity endorsement memilki pengaruh yang signifikan terhadap keputusan tamu menginap di Cottage Daarul Jannah dimana penampilan Aa Gym yang menggunakan atribut jasko serta sorban dan gaya bahasa dialek sunda yang kental banyak ditiru oleh masyarakat sehingga memiliki pengaruh yang besar didalam benak masyarakat tentang sosok Aa Gym.

Pesona Aa Gym sebagai seorang pemimpin pondok pesantren yang baik, ramah dan tegas serta dakwah mengenai ketauhiid juga memiliki nilai tersendiri di masyarakat luas yang membuat masyarakat menjadi tertarik dengan apapun yang disampaikan Aa Gym dan juga unit bisnisnya. Target pasar yang dibidik juga sebagain besar adalah para masayarakat yang ingin mengikuti pengajian di Pesantren Daarut Tauhiid, Keluarga para santri yang ingin mengunjungi keluarganya, Mengantar Jamaah Haji atau umroh, mengikuti pelatihan yang dilaksanakan di Daarut Tauhiid, melakukan bisnis disekitaran Daarut Tauhiid ataupun masayarakat yang ingin merasakan menginap di lingkungan pesantren sehingga 
penilaian responden terhadap dimensi attraction adalah baik.

\section{Dimensi Power}

Secara umum penilaian responden terhadap dimensi power pada variabel celebrity endorsement adalah baik dilihat dari pertanyan mengenai dimensi power yaitu karisma yang dimilki Aa Gym dinilai baik oleh para responden. Karisma Aa Gym sebagai pendakwah sangat besar dan dapat mempengaruhi masayarakat untuk bisa dekat, mengenal dan belajar tentang ketauhiidan sehingga pemilihan Aa Gym sebagai celebrity endorsement Cottage Daarul Jannah yang berada di dalam lingkungan Pesantren Daarut Tauhiid dianggap tepat dan dinilai baik.

E. Penilaian Responden Terhadap Keputusan Tamu Menginap Di Cottage Daarul Jannah.

Terlihat bahwa penilaian responden mengenai keputusan tamu menginap di Cottage Daarul Jannah secara umum termasuk dalam kategori baik, dimana hal ini ditunjukan dengan jawaban responden dari delapan pertanyaan yang diajukan semuanya dinilai baik. Adapun ke delapan pertanyaan tersebut antara lain adalah: kualitas produk yang dimiliki oleh Cottage Daarul Jannah, Keunggulan produk yang dimiliki oleh Cottage Daarul Jannah, kemudahaan pemesanan kamar secara walk in, kemudahan pemesanan kamar melalui booking online, frekuensi pemesanan kamar dan memilih untuk menginap di Cottage Daarul Jannah, frekuensi menginap saat weekdays, frekuensi menginap saat weekend, frekuensi menginap saat liburan. Dari pertanyaanpertanyaan tersebut terlihat bahwa keputusan tamu untuk menginap karena sesuai dengan kebutuhannya.

F. Pengaruh Celebrity Endorsement Terhadap Keputusan Tamu Menginap di Cottage

Daarul Jannah

Permasalahan yang ingin dijawab pada penelitian ini adalah adakah pengaruh celebrity endorsement terhadap keputusan tamu menginap di Cottage Daarul Jannah. Secara empiris, hasil penelitian ini menginformasikan (1) Terdapat pengaruh yang sangat signifikan antara variabel celebrity endorsement terhadap keputusan tamu menginap di Cottage Daarul Jannah. (2) Besarnya pengaruh celebrity endorsement terhadap keputusan tamu menginap ditunjukan oleh hasil penelitian variabel celebrity endorsement yang terdiri dari empat dimensi yaitu: visibility, credibility, attraction, dan power membawa implikasi yang signifikan terhadap keputusan tamu menginap.
Berdasarkan temuan empiris yang menunjukan adanya pengaruh yang signifikan pada celebrity endorsement terhadap keputusan tamu menginap maka hasil penelitian ini memberikan beberapa informasi diantaranya: (1) Terdapat pengaruh yang signifikan antara celebrity endorsement terhadap keputusan tamu menginap di Cottage Daarul Jannah. (2) Celebrity endorsement (Aa Gym) memiliki peranan yang besar dalam keputusan tamu untuk menginap di Cottage Daarul Jannah yang dapat dilihat dari hasil penelitian terhadap celebrity endorsement dengan empat dimensi yang terdiri dari: visibility, credibility, attraction, dan power. Pelaksanaan promosi dengan menggunakan celebrity endorsement (Aa Gym) membawa implikasi yang signifikan terhadap keputusan tamu menginap di Cottage Daarul Jannah dan tidak hanya dipengaruhi oleh celebrity endorsement saja namun juga ada faktor lain (epsilon), yang juga berpengaruh dan tidak dikaji dalam penelitian ini.

Temuan dari hasil penelitian ini membuktikan sebagian besar hipotesis penelitian ini yaitu terdapat pengaruh celebrity endorsement baik secara simultan maupun parsial, pengaruh yang ditimbulkan dari hasil penelitian menunjukan kearah yang positif, yang berarti bahwa promosi dengan menggunakan celebrity endorsement (Aa Gym) terhadap peningkatan jumlah kunjungan tamu menginap di Cottage Daarul Jannah adalah tepat sasaran dimana tamu memutuskan menginap di Cottage Daarul Jannah sebagian besar karena pengaruh celebrity endorsement (Aa Gym)

\section{KESIMPULAN}

Berdasarkan hasil penelitian yang telah dilakukan, maka penulis merekomendasikan bebrapa hal mengenai pengaruh celebrity endorser terhadap keputusan tamu menginap. Celebrity endorsement yang terdiri dari visibility, credibility, attraction, dan power sudah cukup baik hal tersebut ditunjukan dengan tingginya penilaian responden mengenai variabel ini tetapi bila dilihat dari pertanyaan-pertanyaan kepada responden terlihat dari beberapa sub-variabel memiliki nilai tanggapan yang lebih rendah daripada sub-variabel lainnya.

Sub-Variabel Visibility pada pengujian parsial memiliki nilai terkecil yaitu (-682) dimana tidak memiliki pengaruh yang signifikan terhadap sub-variabel ini. Celebrity endorser untuk meningkatkan kembali popularitasnya di masyarakat agar masyarakat dapat mengenal celebrity endorsement (Aa Gym) tersebut. 
Sub-Variabel Credibility dari tiga pertanyaan kepada responden, pertanyaan tentang citra yang mendapatkan penilaian terkecil dimana masyarakat masih ada yang pro dan kontra tentang kehidupan pribadi celebrity endorsement (Aa Gym). Lebih meningkatkan citra baik di masyarakat.

Sub-Variabel Attraction pada pengujian secara parsial memiliki nilai yang paling tinggi (32.399) dimana attraction celebrity endorsement ini yang paling diingat dalam memori konsumen/tamu sehingga tetap perlu di pertahannkan bahkan menciptakan suatu attraction baru yang bisa lebih diingat oleh masyarakat.

Sub-Variabel Power dengan satu item pertanyaan memiliki penilaian yang baik dimana karisma dari celebrity endorsement sampai saat ini masih mempengaruhi tamu/konsumen atau masayarakat.

\section{DAFTAR RUJUKAN}

Abedniya, A. Bardia, Y. .H., \& Majid, N. Z. (2010). Investigative The Impact of Celebrity Endorser on Brand Image.

Arikunto, S. (2008). Prosedur Penelitian Bisnis. Bandung: Alfabeta.

Azwari, S. (2007). Metode Penelitian. Yogya: Pustaka Pelajar.

Belch, et al. (2009) Advertising and Promotion: an Integrated Marketing Comunication Prerspective ( $8^{\text {th }}$ ed). New York: Mc Graw-Hill.

Bergestorm, C. Skarfstad, \& Rikard (2004). Celebrity Endorser. Case study of $\mathrm{J}$. Lindeberg.

Bojanic, D. C. (2008). Houspitality Marketing Mix and Service Marketing.

Buchory, Herry, A., \& Saladin. (2010). Manajemen Pemasaran. Bandung: Linda Karya.

Clow, K.E., \& Black, D. (2002). Integrated Advertising Promotion and Marketing Communication. New Jersy: Pearson Education-Prentice Hall.

Djaslim, S. (2007) Intisari Pemasaran dan Unsur-unsur Pemasaran. Bandung: CV. Linda Karya.

Egan, J. (2001). Strategi Menaklukan Pasar. Jakarta: Gramedia.

Griffin, R. W., \& Ronald J. E. (2006). Bussiness Esential ( ( $^{\text {th }}$ ed). Prentice Hall.

Hasan, A. (2013). Marketing dan kasus-kasus pilihan. Yogyakarta: Center for Academic Publishing Service.

Hurriyanti, R. (2010). Bauran pemasaran dan
Loyalitas Konsumen. Bandung:

Alfabeta.

Husen, A. (1994). Teknik Penarikan Sampel dan Penyusunan Skor. Universitas Padjajaran, Bandung.

Husein, U. (2008). Metode Riset Perilaku Konsumen Jasa. Ghalia Indonesia.

Irawan, K. (2010). Potensi Objek Wisata Air Terjun Serdang, Sebagai Daya Tarik Wisata Di Kabupaten Labuhan Batu Utara. Kertas Karya. Program Pendidikan Non Gelar Pariwisata. Universitas Sumatra Utara.

Kartajaya, H. (2010). Brand Operation The Official MIM Academy course book. Jakarta: Esensi Erlangga Group.

Kotler, P. \& Keller. (2012). Principle of Marketing $\left(14^{\text {th }}\right.$ ed). New York: Prenrice Hall.

Kotler, P. \& Amstrong. (2012). Prinsip-prinsip Pemasaran (Edisi 13, Jilid 1). Jakarta: Erlangga.

Kotler, P. (2000). Marketing Management (Edisi Milenium). Internasional Edition, Prentice Hall.

Leslie, L. Z. (2011). Celebrity in $21^{\text {th }}$ Century. ABC-CLIO, LLC California.

Lovelock, C., \& Jochen, W. (2011). Service Marketing New Jersey. USA: Pearson.

Mashuri, Andi. 2008. Penelitian Verifikatif. Yogya: Media Komputindo.

Moriarty, S. E. (2012). Advertising \& IMC: Principles and Practicing $\left(9^{\text {th }}\right.$ ed). Upper Saddle River,N.J Prentice Hall-Pearson.

Mowen, Jhon. C. \& Minor. M (2002). Perilaku Konsumen (Jilid 1 Edisi Kelima) Jakarta: Erlangga.

Palilati, A. (2007). Pengaruh Nilai Pelanggan \& kepuasan. Jakarta: Elex Media Komputindo.

Peter, J. P., \& Donnelly, Jr. (2011). A Preface to Marketing Manajemen $\left(12^{\text {th }}\right.$ ed). New York: Mc Graw Hill.

Ridwan. (2008). Skala Pengukuran Variabelvariabel Penelitian. Bandung: Alfabeta

Riduan. (2010). Dasar-Dasar Statistika. Bandung: Alfabeta.

Royan. F. M. (2005). Marketing Celebrities. Jakarta: PT. Elex Media Komputindo.

Rohmana \& Rosev. (2014). Analisi Faktorfaktor Motivasi Wisatawan Dalam Mempengaruhi 
Keputusan Berkunjung ke Daya Tarik wisata Cibulan Kuningan.

Lupiyoadi, R. \& Hamdani, A. (2006). Manajemen Pemasaran Jasa. Jakarta: Salemba Empat.

Sarwono, J. (2005). Analisis Data Penelitian Menggunakan SPSS. Yogyakarta: ANDI

Sekaran, U. (2006). Metodologi Penelitian Untuk Bisnis (Edisi 4). Jakarta: Salemba Empat.

Shimp, T. A. (2014). Integrated Marketing Communication inAdvertising.

Sugiyono. (2011). Statistika Untuk Penelitian. Bandung : Alfabeta

Sugiyono. (2012). Metode Penelitian Kombinasi. Bandung: Alfabeta

Sugiyono. (2009). Metode Penelitian Kuantitatif Kualitatif dan $R \& D$. Bandung: Alfabeta.

Susanto, A. B. (2010). Bizmark. Jakarta: Esensi Erlangga Grup.

Tjiptono, F. (2008). Pemasaran Jasa Edisi Pertama. Malang: Bayu Media Publishing.

Tjiptono, F., Gregorius C., Dadi, A. (2008). Pemasaran Strategik. Yogyakarta: Andi.

Ulber, S. (2009). Metode Penelitian Sosial. Bandung: Refika Aditama.

\section{Jurnal}

Agrawal, J. Wagner, A. K. (1995). The Economic worth of Celebrity Endorser: an Event study analysis.

Ahmed, et al. (2012). Effect of Celebrity Endorser on Customer Buying Behaviour, Aprespective from Pakistan.

Choi, S.M. \& Rifon, N. J. (2007). Who is the celebrity in advertising? Understanding dimensions of celebrity images, The Journal of popular Culture

Munyau, Peary K., \& Fred M. M. (2013). The Influence of customer loyality on celebrity endorser choice Decision Marketing: An Explonatory survey of customer of selected celebrity Endorser Product in Kenya. European Journal of Business and Management.

Rismawan, W. (2009). Pengaruh celebrity endorser dan citra merek terhadap keputusan pembelian biscuit oreo.

\section{Website}

www.kemenpar.go.id (30 Juni 2015)

http// www.kemenbudpar.com/

www.muhammaddiryawan.wordpress.com

www.studentjurnal.petra.ac.id/index.php

www.sandi.wordpress.com

http//www.tempo.co/

http//www.travel.kompas.com/

www.venuemagz.com

http//www.unwto.org/ 